\title{
Erratum to: Influence of Anaerobic Digestion Processes on the Germination of Weed Seeds
}

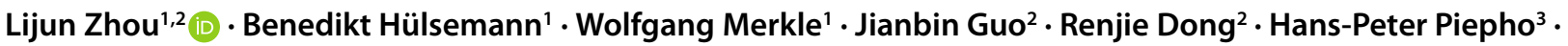 \\ Roland Gerhards ${ }^{4}$. Joachim Müller ${ }^{5} \cdot$ Hans Oechsner $^{1}$
}

Published online: 28 November 2021

(c) The Author(s) 2021

\section{Erratum to:}

Gesunde Pflanzen 2020

https://doi.org/10.1007/s10343-020-00500-y

The article "Influence of Anaerobic Digestion Processes on the Germination of Weed Seeds", written by Lijun Zhou, Benedikt Hülsemann, Wolfgang Merkle, Jianbin Guo, Renjie Dong, Hans-Peter Piepho, Roland Gerhards, Joachim Müller and Hans Oechsner, was originally published Online First without Open Access. After publication in volume 72 , issue 2, page 181-194 the author decided to opt for Open Choice and to make the article an Open Access publication. Therefore, the copyright of the article has been changed to (C) The Author(s) 2020 and the article is forthwith distributed under the terms of the Creative Commons Attribution 4.0 International License, which permits use, sharing, adaptation, distribution and reproduction in any medium or format, as long as you give appropriate credit to the original author(s) and the source, provide a link to the

The online version of the original article can be found under https://doi.org/10.1007/s10343-020-00500-y

Lijun Zhou

lijun.zhou@uni-hohenheim.de

1 State Institute of Agricultural Engineering and Bioenergy, University of Hohenheim, Stuttgart, Germany

2 College of Engineering, China Agricultural University, Key Laboratory for Clean Renewable Energy Utilization Technology, Ministry of Agriculture and Rural Affairs, 100083 Beijing, China

3 Biostatistics Unit (340c), Institute of Crop Science, University of Hohenheim, 70599 Stuttgart, Germany

4 Institute of Phytomedicine (360), University of Hohenheim, 70599 Stuttgart, Germany

5 Institute of Agricultural Engineering, Tropics and Subtropics Group (440e), University of Hohenheim, 70599 Stuttgart, Germany
Creative Commons licence, and indicate if changes were made.

The images or other third party material in this article are included in the article's Creative Commons licence, unless indicated otherwise in a credit line to the material. If material is not included in the article's Creative Commons licence and your intended use is not permitted by statutory regulation or exceeds the permitted use, you will need to obtain permission directly from the copyright holder.

To view a copy of this licence, visit http://creativecommo ns.org/licenses/by/4.0/.

The original article has been corrected.

Funding Open Access funding enabled and organized by Projekt DEAL.

Open Access This article is licensed under a Creative Commons Attribution 4.0 International License, which permits use, sharing, adaptation, distribution and reproduction in any medium or format, as long as you give appropriate credit to the original author(s) and the source, provide a link to the Creative Commons licence, and indicate if changes were made. The images or other third party material in this article are included in the article's Creative Commons licence, unless indicated otherwise in a credit line to the material. If material is not included in the article's Creative Commons licence and your intended use is not permitted by statutory regulation or exceeds the permitted use, you will need to obtain permission directly from the copyright holder. To view a copy of this licence, visit http://creativecommons.org/licenses/by/4. $0 /$.

Lijun Zhou is currently a PhD student in the State Institute of Agricultural Engineering and Bioenergy at the University of Hohenheim, Germany, since November 2016. After the completion of the Master in Sustainable Water Management in Sweden in October 2012, she worked for 4 years in the agricultural and renewable energy sector in China for international financed projects. The main objective of her $\mathrm{PhD}$ is to establish a biogas plant measurement program in China which can fit the Chinese situation and needs, based on the methodology derived from the German Biogas Measurement Program III, so that she can make a comprehensive comparison study on full-scale agricultural biogas plant operation performance in Germany and China, from the technical, policy and financial aspects. 